\title{
DISCARDS OF THE INDONESIAN TUNA LONGLINE FISHERY IN INDIAN OCEAN
}

\author{
Bram Setyadji and Budi Nugraha \\ Research Institute for Tuna Fisheries Benoa \\ Received January 07-2013; Received in revised form June 03-2013; Accepted June 10-2013 \\ email: bram.setyadji@gmail.com
}

\begin{abstract}
Incidental by-catch and associated discarding are difficult to estimate on the basis of logbook information because they are poorly reported by fishing masters and their importance varies with several interrelated factors. The purpose of this paper is to inform the commonly discarded fishes of the Indonesian tuna longline fishery in the Indian Ocean. The study was carried out during $2010-$ 2011 following six commercial tuna longline vessels based in Port of Benoa. Discards composition was dominated by longnose lancetfish and pelagic stingrays which composed almost half of total discards. Almost half of total catch are discards and half of discards are disposed dead or dying.
\end{abstract}

KEYWORDS: By-catch, discards, longline, Indian Ocean

\section{INTRODUCTION}

The term "by-catch" is widely used in scientific or popular literature which has variety of interpretation, and some might overlapping or contradictory. But in general it can be described as a fraction of the catch that consists of non-target species (Romanov, 2002, Pauly, 1984, Alverson \& Hughes, 1996). By definition, by-catch is pre-determined, while the decision to retain or discard may occur during the fishing take place, at some time later during the vessel trip, or, at times, on return to port. Following Alverson et al. (1994)by-catch has been customarily used to identify (1) species retained and sold, (2) species or sizes and sexes of species discarded as a result of economic, legal, or personal considerations, and (3) non-targeted species retained and sold, plus all discards.

By-catch has two components: by-product, the non-target species that is retained and sold (Chapman, 2001) and discards, is a portion of the catch returned to the sea as a result of economic, legal, or personal considerations (Alverson et al., 1994). It has either no or limited commercial value (Chapman, 2001) but might play important ecological role.

Incidental by-catch and associated discarding are difficult to estimate on the basis of logbook information because they are poorly reported by fishing masters and their importance varies according to interrelated factors (Rochet and Trenkel, 2005). The issues raised from by-catch and discarding are, however, of increasing concern because such practices are responsible for economic loss, juvenile mortality, ecological effects on key species that are relevant to the overall ecosystem structure and functioning, and added threat to endangered or high ethical value species (Amande et al., 2008).
However concern on this matter, especially in the Indian Ocean was little and the information available are so far limited, while the issue of by-catch has become particularly significant in the region. The purpose of this paper is to describe information of the discards on tuna longline fishery in Indian Ocean including catch rate, nominal CPUE and condition at release from $109-122^{\circ} \mathrm{E}$ and $10-16^{\circ} \mathrm{S}$ of Indian Ocean.

\section{MATERIALS AND METHODS}

\section{Study Area and Data Sampling}

The data analyzed were part of the result of numerous trips from onboard observation following commercial tuna longline vessels conducted from 2010 - 2011. In this study category discards is assigned to a portion of the catch returned to the sea as a result of economic, legal, or personal considerations (Alverson et al., 1994) and it has either no or limited commercial value (Chapman, 2001). These data were taken on a daily $5 \times 5$-degree square basis by vessel, fishing date, location of deployment, number of hooks, condition at release, daily deployed hooks, catch in number and length (FL), while weight never been measured. Samples were taken during fishing operation in Indian Ocean (south of Java and Nusa Tenggara) as shown in Figure 1.

\section{Nominal CPUE (Catch Per Unit Effort)}

The nominal CPUE in tuna longline fishery was described as the number of hooks used on certain area of fishing, while hook rates calculated as number of fishes caught per 100 hooks. 


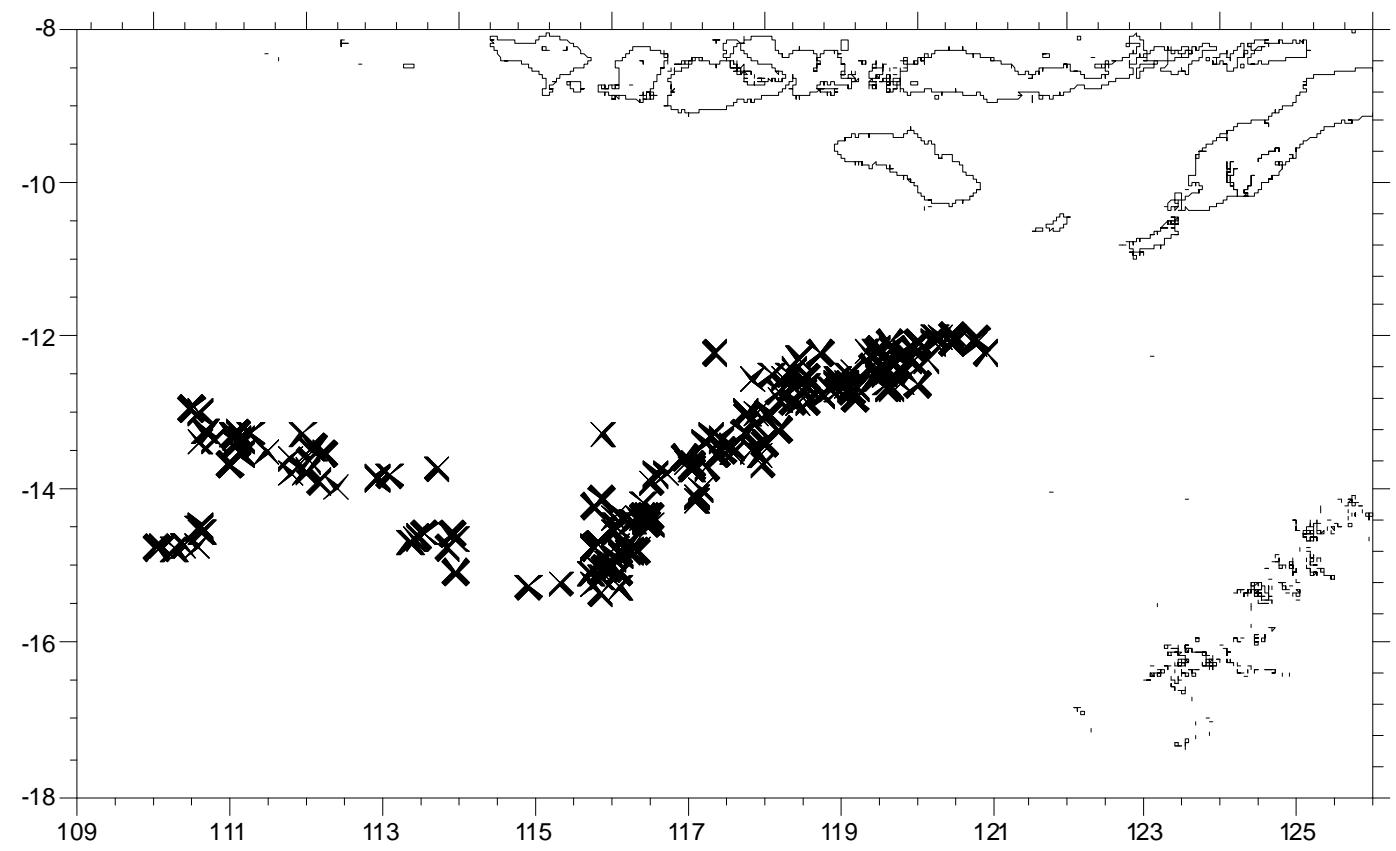

Figure 1. Study area and location of the 6 longline vessels fishing ground.

\section{RESULTS}

\section{Catch Composition}

A total 5,570 species of fishes, reptiles, and sea mammal during 2010 - 2011 were managed to be recorded and classified onto two groups which is target species comprised of albacore (Thunnus alalunga), yellowfin tuna (Thunnus albacares), and bigeye tuna (Thunnus obesus); and non-target species, consist of by-product and discards.

The catch of tuna as target species only contributed $18.47 \%$ of total catch and $81.52 \%$ were catagorised as by-catch with discards dominated with $51.11 \%$ followed by by-product with $30.41 \%$ (Table 1 ).
Regardless of target and by-product, discards composition was dominated by longnose lancetfish (Alepisaurus ferox) $32.73 \%$ and pelagic stingrays (Pteroplatytrygon violacea) $11.62 \%$ which comprised almost half of total discards. Later followed by crocodile shark (Pseudocarcharias kamoharai) $6.07 \%$, snake mackerel (Gempylus serpens) $0.41 \%$, ocean sunfish (Mola mola) $0.14 \%$, olive ridley turtle (Lepidochelys olivacea) $0.07 \%$, and hammerhead shark (Sphyrna sp.), tappertail ribbonfish (Trachipterus fukuzakii), false killer whale (Pseudorca crassidens), alongside with leatherback sea turtle (Dermochelys coriacea) which composed each $0.02 \%$ (Figure 2).

Table 1. The catch composition of tuna longline vessels based in Port of Benoa.

\begin{tabular}{cccccccc}
\hline \multirow{2}{*}{$\begin{array}{c}\text { Vessel } \\
\text { Code }\end{array}$} & $\begin{array}{c}\text { Number of } \\
\text { Catch }\end{array}$ & \multicolumn{2}{c}{ Target } & \multicolumn{2}{c}{ By-Product } & \multicolumn{2}{c}{ Discards } \\
\cline { 3 - 7 } & $\mathbf{N}$ & $\%$ & $\mathbf{N}$ & $\%$ & $\mathbf{N}$ & $\%$ \\
\hline LL_01 & 1,054 & 141 & 13.38 & 142 & 13.47 & 771 & 73.15 \\
LL_02 & 936 & 235 & 25.11 & 140 & 14.96 & 561 & 59.94 \\
LL_03 & 926 & 377 & 40.71 & 124 & 13.39 & 425 & 45.90 \\
LL_04 & 848 & 309 & 36.44 & 131 & 15.45 & 408 & 48.11 \\
LL_05 & 670 & 353 & 52.69 & 216 & 32.24 & 101 & 15.07 \\
LL_06 & 1,136 & 279 & 24.56 & 276 & 24.30 & 581 & 51.14 \\
\hline Total & $\mathbf{5 , 5 7 0}$ & $\mathbf{1 , 6 9 4}$ & $\mathbf{3 0 . 4 1}$ & $\mathbf{1 , 0 2 9}$ & $\mathbf{1 8 . 4 7}$ & $\mathbf{2 , 8 4 7}$ & $\mathbf{5 1 . 1 1}$ \\
\hline
\end{tabular}




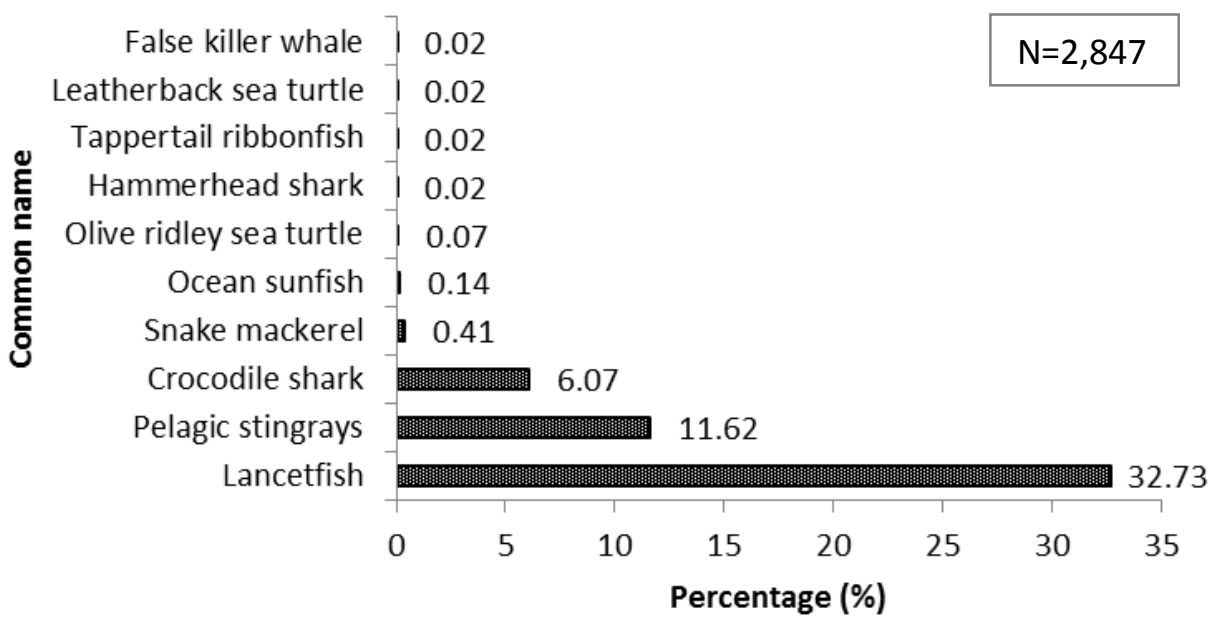

Figure 3. Composition of discards recorded from tuna longline vessels based in Port of Benoa.

\section{Nominal CPUE (Catch Per Unit Effort).}

Total 262,527 hooks were set from six vessels during $2010-2011$ and longnose lancetfish got the most hook rate with 0.645 per 100 hooks followed by pelagic stingrays, crocodile shark, and snake mackerel with $0.237,0.073$, and 0.008 per 100 hooks. While the other also occurred but occasionally to rare, like the present of tappertail ribbonfish, hammerhead shark, false killer whale, and leatherback sea turtle which only popped out once with hook rate 0.0004 per 100 hooks (Table 2).
The CPUE of longnose lancetfish was the highest even among target species, even if compared the hook rate of yellowfin tuna, bigeye tuna and albacore.

\section{Catch at Release}

Of total 3,398 catch at release data (in number), $27.93 \%$ were informed released alive, $24.75 \%$ injured, $4.37 \%$ dying, $42.78 \%$ dead, and $0.18 \%$ wrecked (Table $3)$.

Table 3. The catch composition of tuna longline vessels based in Port of Benoa.

\begin{tabular}{lrrrrrr}
\hline Vessel Code & A1 & A2 & A3 & A4 & A5 \\
\hline LL_01 & 19 & - & 43 & 39 & - \\
LL_02 & 175 & - & 04 & 228 & - \\
LL_03 & 86 & - & 27 & 309 & 3 \\
LL_04 & 140 & 3 & 25 & 392 & 1 \\
LL_05 & 212 & 557 & - & - & - \\
LL_06 & 846 & - & 38 & 248 & 3 \\
\hline TOTAL & 1478 & 560 & 137 & 1216 & 7 \\
\hline
\end{tabular}

Remarks: A1 (alive), A2 (injured), A3 (dying), A4 (dead), A5 (wrecked). 


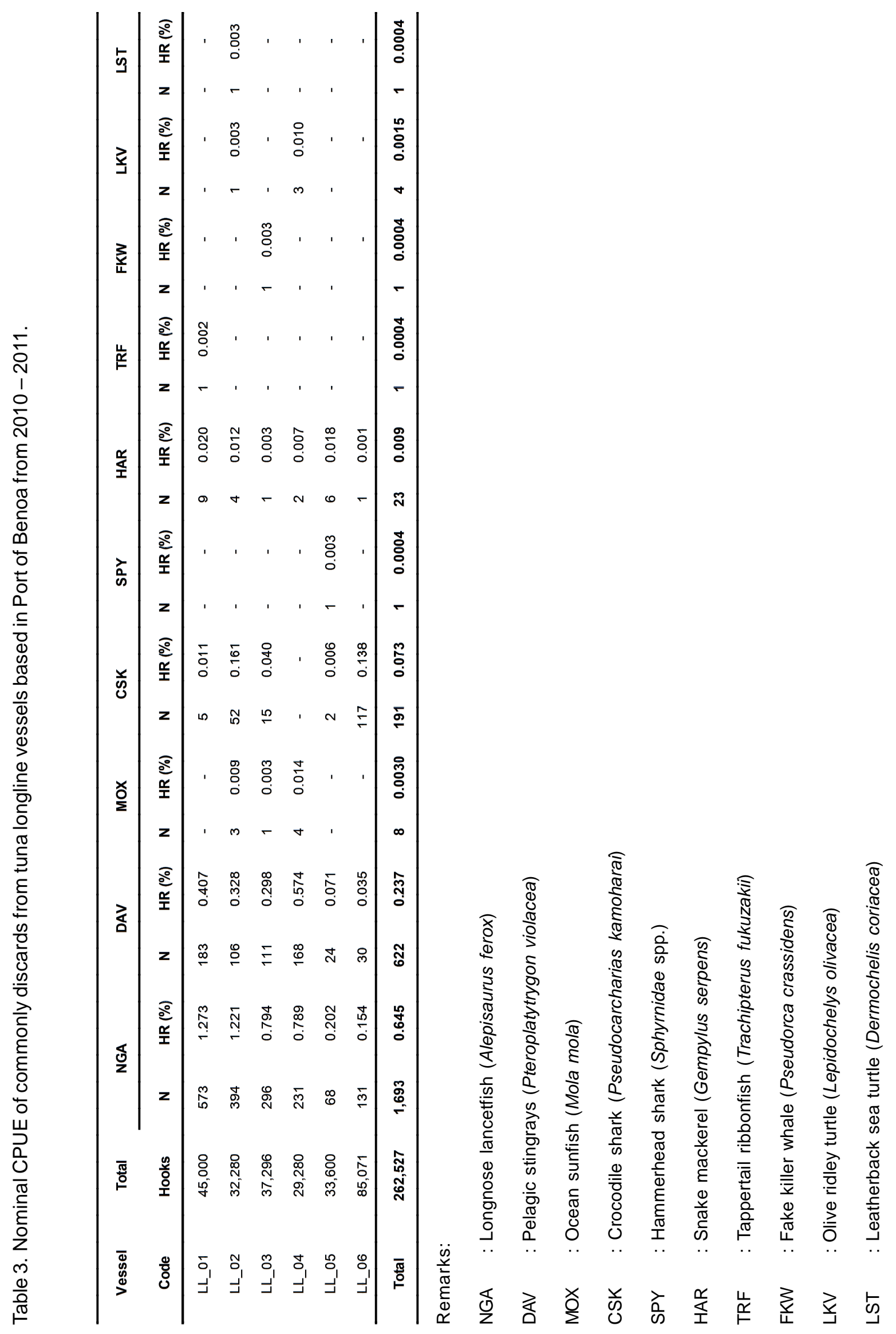




\section{DISCUSSION}

\section{Catch Rate}

The catch composition of target species (in number) was lower compared to that in Pacific Island Countries' Tuna Fishery Area (PICTFA) (Chapman, 2001) but higher than in Eastern Indian Ocean and Andaman Sea which target species was only as much as $13.51 \%$ of total tuna (yellowfin and bigeye) caught from total catch (Rajruchithong et al., 2005). The high catch rate of longnose lancetfish and pelagic stingrays are likely appears in tuna longline fishery in Indonesia i.e. Banda Sea (72.04\%, regardless the main catch) (Nugraha \& Wagiyo, 2006), South of Java (57.73\%, regardless the main catch) (Nugraha \& Triharyuni, 2009), and West Sumatra (22.45\%) (Nugraha \& Nurdin, 2006). Combined they composed almost half of the total catch (in number) resulted in high CPUE which is $0.645 / 100$ hooks and $0.237 / 100$ hooks, respectively. Since the species has no commercial value and, to avoid loosing the hook, fishermen discard individuals at sea in such poor condition that survival probabilities are low.

The high catch rate for by-catch, especially discards may have been caused by the type of longline used. Chapman (2001) informed that deep-water sets account for more target species (\% by number), with less discards in both tropical and subtropical waters than shallow sets. While the day-night factor is probably not as significant as the shallow-deep factor in determining the amount of discards taken by longliners. But why is that Indonesian fleets still producing a large number of by-catch eventough deepwater longline was commenced since 1983? (Sadiyah, 2012). The answer probably lies on the type and size of the hook used. Indonesian longliners familiar with conventional $\mathrm{J}$-hook size 3 which is smaller compared to other country reported (Read, 2006; Xu et al., 2006). Using both circle hook and larger J-hook are believed to have impact of reducing the catch rate of discards (Piovano et al., 2010; Domingo et al., 2012; ) and its survival rate (Pacheco et al., 2011) especially for pelagic stingrays and marine turtles.

\section{Catch at Release}

Of total discards recorded, $27.93 \%$ released alive, $24.75 \%$ injured, $4.37 \%$ dying, $42.78 \%$ dead, and $0.18 \%$ wrecked. This shows that most of the discards are released dead or with little survival probability and it should be a concern. Indeed most of the species released are less economically valuable but it might ecologically important. So a step of action should be taker in order to not "wasting the sea", noting that almost half of the total catch are released back. A more in-depth research is needed to investigate the effect of discards both economically and ecologically.

\section{Some Ecological Information on Discarded Species}

Longnose lancetfish may play an important role on pelagic food chain as a predator on micronecton organisms (Romanov et al., 2008a) and a prey for billfishes and tunas (Potier et al., 2007a), and together they usually form a schooling. Despite of their massive abundace in the ocean yet no information about the utilisation of this species, especially longnose lancetfish which perhaps due to the number of fine bones (which is a lot) and considerably high moisture content in the muscle (Wada et al., 1976), but scientists find it benefit for studying food chains in the pelagic ecosystem because of their digestive characterisctics: food is stored in the stomach and digestion occurs in the intestine (Potier et al., 2007b after Rofen, 1966). While pelagic stingrays has been locally listed in the IUCN "Near Threatened" category based on a precautionary approach (Cavanagh \& Gibson, 2007).

There were 2 species of sharks which were recorded as discards, crocodile and hammerhead shark. The bigger portion goes to crocodile shark which becomes abundant species in several areas of World Ocean, in particular Southern Indian Ocean (Romanov \& Levesque, 2009) and informed to have highest catch rate in Indian Ocean, while off Western Australia become most frequently caught species (Romanov et al., 2008b). Hammerhead sharks (family: Sprynidae) are listed as vulnerable and endangered due to it ranked among the species with lowest prductivity. Even tough most of sharks caught were drag back to the port, these sharks were unlikely, they usually released dead and utilised especially for their fins while their bodies are disposed.

Not much knowledge about snake mackerel and tappertail ribbonfish, they usually are caught alongside tuna longline fishery but in a minor number (Froese \& Pauly, 2009). Snake mackerel is usually marketed frozen or in sausages and fish cakes, in Hawaii, this fish is known as hāuliuli and is considered good eating cooked or fish (Nakamura \& Parin, 1993). There yet an information about the utilisation of tapertail ribbonfish, the only interesting fact is that this fish also commonly called "earthquake fish" in Taiwan because the fish are popularly believed to appear following major earthquake events due to alleged sensitivity to disturbances in the ocean floor. 
Except in Indonesian waters, the present of ocean sunfish also mentioned by Gamblin et al. (2007) in Seychelles waters. Ocean sunfish or common mola is the heaviest known bony fishes and has an average adult weight of $1,000 \mathrm{~kg}$ (Pope et al., 2009), they are recognized as the most fecund extant vertebrate with a single female capable of producing as many as 3,108 eggs at one time (Bass et al., 2005 after Parenti, 2003). The meat of the ocean sunfish is considered a delicacy in some regions, the largest markets being Taiwan and Japan. All parts of the sunfish are used in cuisine, from the fins to the internal organs (Froese \& Pauly, 2009).

False killer whale is a cetacean, marine mammal and the third largest member of the oceanic dolphin family (Delphinidae). Knowledge about this species is limited, the only known issue is that this species like to graze longline bait-caught fishes during hauling.

Two kind of sea turtle recorded during this study, the first is olive ridley sea turtle which occured 4 times, and leatherback sea turtle only once. All of them are released alive with minor injuries. The olive ridley sea turtle is a small extant sea turtle with distribution across Indian Ocean, usually appear as by-catch in longline fisheries but mostly caught by 'ghost fishing" (nets or bits of net that have been lost or jettisoned) (Anderson et al., 2009). According to the observations, $L$. olivacea seems the most impacted by the fishery and most of the by-catches occurred in the north of the west Indian Ocean (up to the equator) (Amande et al., 2008). Leatherback sea turtle is known to be the largest of all living sea turtles but yet little information about their life history.

\section{CONCLUSION}

Discards composition was dominated by longnose lancetfish and pelagic stingrays which composed almost half of total discards, with almost half of total catch are discards and half of discards are disposed dead or dying. Almost half of total catch are discards and half of discards are disposed dead or dying.

\section{AKNOLEDGEMENT}

This paper is part of authors' contribution in research on by-catch and tuna fisheries in Indian Ocean conducted during 2010-2011 under Research Institute for Marine Fisheries. Authors would also like to thank to all of scientific observers for their contribution in collecting onboard data throughout the years. With gratitude to Indonesian Tuna Longline company for their support for years of research.

\section{REFERENCES}

Anderson, R.C., Zahir, H., Jauharee, R., Sakamoto, T. \& I. Sakamoto. 2009. entanglement of Olive Ridley Turtles Lepidochelys olivacea in ghost nets in the equatorial Indian Ocean. IOTC-2009-WPEB$07.11 \mathrm{p}$.

Alverson, D.L., Freeberg, M.H., Pope, J.G., \& S.A. Murawski. 1994. A global assessment of fisheries bycatch and discards. FAO Fisheries Technical Paper 339, Rome: FAO. 233 p.

Alverson, D.L. \& S.E. Hughes. 1996. By-catch: from emotion to effective natural resource management. Review in fish Biology and fisheries 6; p.443-442.

Amande, J.M., Ariz, J., Chassot, E., Chavance, P., Delgado, DM, A., Gaertner, D., Murua, H., Pianet, R. \& J. Ruiz. 2008. Bycatch and discards of the European purse seine tuna fishery in the Indian Ocean. Estimation and characteristic for the 20032007 period. Paper presented in Ecosystem and By-catch Working Group. 20 - 22 October 2008, Bangkok, Thailand.

Bass, A.L., Dewar, H. \& T. Thys. 2005. Evolutionary divergence among lineages of the ocean sunfish family, Molidae (Tetraodontiformes). Marine Biology (2005). 9 p.

Cavanagh, R.D. \& C. Gibson. 2007. Overview of the Conservation Status of Cartilaginous Fishes (Chondrichthyans) in the Mediterranean Sea. IUCN,Gland, Switzerland and Malaga, Spain.

Chapman, L. 2001. Bycatch in the tuna longline fishery. $2^{\text {nd }}$ SPC Heads of Fisheries Meeting (Noumea, New Caledonia, 23-27 July 2001).

Domingo, A., Pons, M., Jimenez, S., Miller, P., Barcelo, C. \& Y. Swimmer. 2012. Circle hook performance in the Uruguayan pelagic longline fishery. Bulletin of Marine Science. 88 (3): 499511.

Froese, R \& D. Pauly. 2009. Snake Mackerel (Gempylus serpens Cuvier, 1829) in http:// www.fishbase.org/summary/Species Summary. php?genusname $=$ Gempylus \& speciesname =serpensdownloaded December22 ${ }^{\text {nd }}, 2011$. 
Gamblin, C., Pascal, B. \& V. Lucas. 2007. Comparison of bycatch species captured during daytime and nightime: preliminary results of longline experiments carried out in Seychelles waters. $A$ document presented to the Indian Ocean Tuna Commission Working Party on Ecosystem and Bycatch in 2007.

Nakamura, I \& N.V. Parin.1993. Snake mackerels and cutlassfishes of the world (Families Gempylidae and Trichiuridae). An annotated and illustrated catalogue of the snake mackerels, snoeks, escolars, gemfihes, sackfishes, domine, oilfish, cutlassfishes, scabbardfishes, hairtails, and frostfishes known to date.FAO Fisheries Synopsis. 15 (125): $136 \mathrm{p}$.

Nugraha, B \& E. Nurdin. 2006. Penangkapan tuna dengan menggunakan kapal riset M.V. SEAFDEC di perairan Samudera Hindia. BAWAL: 1, (3): 95 $-105$.

Nugraha, B \& K. Wagiyo. 2006. Hasil tangkap sampingan (by-catch) tuna long line di perairan Laut Banda. BAWAL: 1 (2): 71 -75.

Nugraha, B \& S. Triharyuni. 2009. Pengaruh suhu dan kedalaman mata pancing rawai tuna (tuna long line) terhadap hasil tangkapan tuna di Samudera Hindia. J. Lit. Perikan. Ind. 15 (3): 239 - 247.

Pacheco, J.C., Kerstetter, D.W., Hazin, F.H., Hazin, H., Segundo, R.S.S.L., Graves, J.E., Carvalho, F. \& P.E. Travassos. 2011. A comparison of circle hook and $J$ hook performance in a western equatorial Atlantic Ocean pelagic longline fishery. Fisheries Research 107: 39-45.

Pauly, D. 1984. Fish population dynamics in tropical waters: A manual for use with program-mable calculators. ICLARM Studies reviews. (8) 325 p.

Piovano, S., Clo, S. \& C. Giacoma. 2010. Reducing longline by catch: The larger the hook, the fewer the stingrays. Biological Conservation 143: 261264.

Pope, E.C., Hays, G.C., Thys, T.M., Doyle, T.K., Sims, D.W., Queiroz, N., Hobson, V.J., Kubicek, L. \& J.D.R. Houghton. 2010. The biology and ecology of the ocean sunfish Mola mola: a review of current knowledge and future research perspectives. Rev Fish Biol Fisheries.17 p.
Potier, M., Marsac, F., Cherel, Y., Lucas, V., Sabati'e, R., Mauryb, O \& F. M'enard. 2007a. Forage fauna in the diet of three large pelagic fishes (lancetfish, swordfishand yellowfin tuna) in the western equatorial Indian Ocean. Fisheries Research. 83: 60-72.

Potier, M., Menard, F., Cherel, Y., Lorrain, A., Sabatie, R. \& F. Marsac.2007b. Role of pelagic crustaceans in the diet of the longnose lancetfish (Alepisaurus ferox) in the Seychelles waters. African Journal of Marine Science 29 (1): 113-122.

Prisantoso, B.I., Widodo, A.A., Mahiswara. \& L. Sadiyah. 2010. Beberapa jenis hasil tangkap sampingan (by-catch) kapal rawai tuna di Samudera Hindia yang berbasis di Cilacap. J. Lit. Perikan. Ind. 16 (3): 185 - 194.

Read, A.J. 2006. Do circle hooks reduce the mortality of sea turtles in pelagic longlines? A review of recent experiments. Center for Marine Conservation. Nicholas School of the Environment and Earth Sciences. Duke University Marine Laboratory. $40 \mathrm{p}$.

Rochet, M.J \& V.M. Trenkel. 2005. Factors for the variability of discards: assumptions and field evidence. Can.J.Fish.Aquat. Sci. 62: 224-235.

Rajruchithong, S., Prajakjitt, P. \& S. Siriraksophon. 2005. Bycatch from tuna purse seine and longline fishing gears in the eastern Indian Ocean by MV SEAFDEC. IOTC-2005-WPBy-07.8 p.

Romanov, E.V. 2002. Bycatch in the tuna purse-seine fisheries of the western Indian Ocean.Fish. Bull. 100(1): 90-105.

Romanov, E.V., Ménard,F., Zamorov, V.V \& M. Potier.2008a. Variability in conspecific predation among longnose lancetfish Alepisaurus ferox in the western Indian Ocean. Fisheries Science; 74: 62-68.

Romanov, E.V., Ward, P., Levesque, J.V. \& E. Lawrence. 2008b. Preliminary analysis of crocodile shark (Pseudocarcharias kamoharai) distribution and abundance trends in pelagic longline fisheries [draft]. IOTC Working Party on Environment and Bycatch (WPEB) Bangkok, Thailand (20 - 22 October, 2008). 29 p. 
Romanov, E.V. \& J.C. Levesque.2009. Crocodile shark (Pseudocarcharias kamoharai) distribution and abundance trends in pelagic longline fisheries [abstract]. IOTC-2009-WPEB-inf01.

Sadiyah, L. 2012. An evaluation of Indonesia's Indian Ocean tuna longline fisheries based on CPUE information. https://docs.google.com/viewer? url=ftp\%3A\%2F\%2Fftp.marine.csiro.au\%2Fpub\%2 Fproctor craig\%2FFinal\%2520 Report\%2520 Doc1\%2520\%2520An\%2520evaluation\%2520of\% 2520 Indonesia's\%252010\%2520tuna\% $2520 \mathrm{LL} \% 2520 \mathrm{fishery} \mathrm{Lilis \% 2520}$
Sadiyah\%2520presentation.pdf. Downloaded on September16 ${ }^{\text {th }}, 2013$.

Wada, S., Koizumi, C. \& J. Nonaka. 1976. Lipids analysis of baracuda and longnose lancetfish. Bulletin of the Japanese Society of Scientific Fisheries. 42(10):1145-1151.

Xu, L., Song, L., Gao, P., Jiang, W. \& J. Wang. 2006. Catch rate comparison between circle hooks and ring hooks in the tropical high seas of the Indian Ocean based on the observer data. IOTC-2006WPTT-12. $6 \mathrm{p}$. 